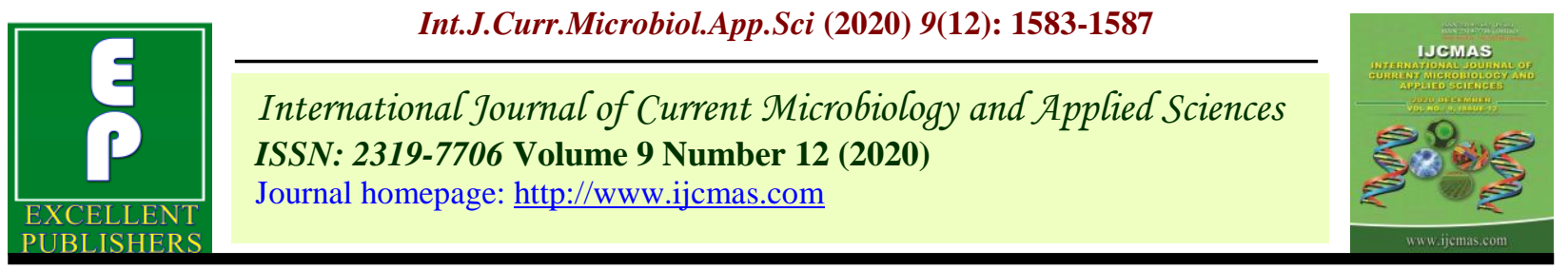

\title{
Influence of Bright Sunshine Hours, Photothermal, Heliothermal and HUE of Rice Cultivars Growing under varying Environment
}

\author{
Deependra Singh", S. R. Mishra, Rakesh Kushwaha and Ram Singh \\ Department of Agro-meteorology, Acharya Narendra Deva University of Agriculture \& \\ Technology, Kumarganj, Ayodhya, (U.P.) India \\ *Corresponding author
}

\begin{tabular}{|c|c|}
\hline & A B S T R A C T \\
\hline $\begin{array}{l}\text { Ke y w o r d s } \\
\text { HUE, BSS, } \\
\text { Heliothermal, } \\
\text { Photothermal }\end{array}$ & $\begin{array}{l}\text { A field experiment was conducted during kharif season of } 2015 \text { at the AN.D.U.A. \& T. } \\
\text { Kumarganj, Ayodhya (U.P.). The experiment consisted of nine treatment combinations } \\
\text { comprised of three transplanting dates viz., July } 5^{\text {th }} \text {, July } 15^{\text {th }} \text { and July } 25^{\text {th }} \text { and three } \\
\text { varieties viz., Sarjoo- } 52 \text {, NDR-359 and Swarna Sub- } 1 \text {. Highest photothermal unit was } \\
\text { recorded in I } I^{\text {st }} \text { date of transplanting on July } 5^{\text {th }} \text { at vegetative stage }\left(22270.5^{0} \text { days hrs.) and }\right. \\
\text { reproductive stage }\left(28863.9^{0} \text { days hrs.) which was superior over July } 15^{\text {th }} \text { at vegetative }\right.\end{array}$ \\
\hline Article Info & stage $\left(21435.3^{0}\right.$ days hrs. $)$, reproductive stage $\left(28210.6^{\circ}\right.$ days hrs. $)$ and July $25^{\text {th }}$ at \\
\hline $\begin{array}{l}\text { Accepted: } \\
12 \text { November } 2020 \\
\text { Available Online: } \\
10 \text { December } 2020\end{array}$ & $\begin{array}{l}\text { Heat use efficiency (HUE) was recorded in growing environment of July } 15^{\text {th }}\left(0.499 \mathrm{gm}^{-2}\right. \\
0 \text { days }) \text { transplanting at all the stage followed by July } 5^{\text {th }}\left(0.474 \mathrm{gm}^{-2} 0 \text { days }\right) \text { and July } 25^{\text {th }} \\
\left(0.448^{0} \text { days }\right) \text { transplanting while among the variety NDR-359 }\left(0.503 \mathrm{gm}^{-2}{ }^{-2} \text { days }\right) \text { recoded } \\
\text { highest HUE followed by Swarna Sub-1 }\left(0.475 \mathrm{gm}^{-2} \text { days }\right) \text { and Sarjoo-52 }\left(0.457 \mathrm{gm}^{-2}\right. \\
{ }^{0} \text { days). }\end{array}$ \\
\hline
\end{tabular}

\section{Introduction}

Rice (Oryza sativa L.) is one of the important foods for most people living in India. It is being grown under diverse agro-climatic condition at wide range of latitudes. It is essential to human diet in India as it is a richest source of carbohydrates and adds the proteins component in human diet too. Generally $6.8 \%$ protein, $78.2 \%$ carbohydrates, $0.5 \%$ fat and $0.6 \%$ mineral matters are found in rice hence it is primarily used as a staple food crop. The rice is cultivated worldwide in area 156.80 million hectare having an annual production of 680.19 million tonnes and an average productivity of 5.15 tonnes per hectare (Anonymous, 2013-14).) . In the latest report, In India, during 2014-15, the rice crop had production of 103.04 million tonnes. In Uttar Pradesh it was grown on over all area 50.94 million hectare with production of 15.30 million tonnes. The average productivity of Uttar Pradesh is $257.3 \mathrm{~kg} / \mathrm{ha}$ which is more than the average national productivity. In Uttar Pradesh it is grown in about $6.20 \mathrm{~m}$ ha which comprises of $13.5 \%$ of total rice in India. (Anonymous, 2013-2014). Rice (Oryza 
sativa L.,) belongs to the family Gramineae, genus Oryza and has two cultivated and 22 wild species. The cultivated species are Oryza sativa and Oryza glaberrima. Oryza sativa is grown all over the world while Oryza glaberrima has been cultivated in West Africa for the last $\sim 3500$ years. Most rice researchers agree that the area of Oryza sativa is located in a belt extending from the AssamMeghalaya area in India to mountain ranges in the mainland Southeast Asia and Southwest China. Rice is the most important staple food for a large part of the world's population, especially in East and South Asia, the Middle East, Latin America, and the West Indies. As the population increases rapidly in these regions, the demand for rice will grow to an estimated 2000 million metric tons by 2030 (FAO, 2002). In2010-2011, area covered under rice was $59.25 /$ ha with productivity of $21.20 \mathrm{q} / \mathrm{ha}$. (Dwivedi, 2011).

Rice is grown under different conditions. Rice is the only cereal crop that can grow for long periods of time in standing water. $57 \%$ of rice is grown on irrigated land, $25 \%$ on rainfed lowland, $10 \%$ on the uplands, $6 \%$ in deepwater, and $2 \%$ in tidal wetlands. Rice is one of the most important cereal crop belong to the family Graminae. It is the staple food for half of the world's population. Rice is cultivated of worldwide in area of 156.80 million hectare having an annual production of 650.19 million tonnes. Among the rice growing countries, India stands first in area and second in production next after China. Uttar Pradesh is largest rice growing state after West Bengal in the country. Rice production in Asia has increased by 2.6 times since 1961, primarily as a result of the "Green Revolution", which dramatically increased the rice productivity in the high input irrigated system (Khus, 1997). The rainfed systems, which occupy about $32 \%$ of the rice-growing area in Asia, have been less from the 'Green Revolution'. According to GRSP (Global
Rice Science Partnership) Annual Report, 2011, rice production on 60 million hectares of rainfed areas in Asia and almost 7 million hectares in sub-Saharan Africa remain low $(0.5-2.5 \mathrm{t} / \mathrm{ha})$ and unstable due to frequent drought or flooding.

These events can occurs in different years, or both can happen in the same season during different crop growth periods. The yield of rice is stagnating around $\leq 2.0 \mathrm{tq} / \mathrm{ha}$ since 2001-2002 except in the year 2002-2003, 2004-2005 and 2009-2010 due to erratic rainfall distribution causes excess water stagnation/drought or both in different years.

\section{Materials and Methods}

An experiment was conducted during Kharif season of 2015 at Agro-meteorology Research Farm of A.N.D. University of Agriculture and Technology, Kumarganj, Ayodhya (U.P.). The experiment was conducted in Randomized Block Design (RBD) and replicated the three times. The different growth parameters studied were rice as Heat Use Efficiency (HUE), Bright Sunshine Hours (BSS), Heliothermal, Photothermal.

\section{Results and Discussion}

Heat use efficiency (HUE) $\left(\mathrm{g} / \mathrm{m}^{2} /{ }^{0}\right.$ days) of rice cultivars at different growing environment has been depicted in (Table 1). The maximum Heat use efficiency ( $\mathrm{g} / \mathrm{m}^{2} /{ }^{0}$ days) $(0.499)$ was recorded at $\mathrm{II}^{\text {nd }}$ date of transplanting on July $15^{\text {th }}$ at 105 DAT followed by July $5^{\text {th }}(0.474)$ and July $25^{\text {th }}$ (0.448). Among the varieties, NDR-359 possess highest Heat use efficiency $(0.503)$ at 105 DAT followed by Swarna Sub-1(0.475) and Sarjoo-52 (0.457). The similar results found that by Nishad et al., (2018) the experiment consisted of nine treatment combinations comprised of three transplanting dates viz., July 5 th, July $15^{\text {th }}$ and 
July 25th and three varieties viz., NDR-97, NDR-3112 and BPT-5204. Results reveal that Highest Heat use efficiency (HUE) was recorded in growing environment of July 25th transplanting at all the stage followed by July 15th and July 5th transplanting while among the variety NDR-3112 recoded highest HUE followed by BPT-5204and NDR-97.

Bright sunshine (hrs.) of rice cultivars at different growing environment has been depicted in (Table 2). From table it was revealed that highest bright sunshine (hrs.) was recorded at $\mathrm{II}^{\text {st }}$ date of transplanting on (669.8) July $15^{\text {th }}$ followed by (661.6) July $5^{\text {th }}$ and (598.8) July $25^{\text {th }}$ respectively. Among the varieties bright sunshine hours were recorded highest in cultivar NDR-359 (633.8) followed by Sarjoo-52(633.8) and Swarna Sub1(627.6). Samanta et al., (2019) Irrespective of years, Swarna cultivar used the radiation more efficiently than the Satabdi cultivar. The mean RUE values were 2.75 and 2.57 gm MJ1 IPAR for Swarna and Satabdi cultivars respectively.

Table.1 Heat use efficiency (HUE) as affected by different growing environment of rice cultivars

\begin{tabular}{|l|c|c|c|c|c|c|c|}
\hline Treatments & \multicolumn{7}{|c|}{ Heat use efficiency $\left(\mathbf{g} / \mathbf{m}^{2} / \mathbf{l}\right.$ days $)$} \\
\hline $\begin{array}{l}\text { Growing } \\
\text { environment }\end{array}$ & $\begin{array}{c}\mathbf{1 5} \\
\text { DAT }\end{array}$ & $\begin{array}{c}\mathbf{3 0} \\
\text { DAT }\end{array}$ & $\begin{array}{c}\mathbf{4 5} \\
\text { DAT }\end{array}$ & $\begin{array}{c}\mathbf{6 0} \\
\text { DAT }\end{array}$ & $\begin{array}{c}\mathbf{7 5} \\
\text { DAT }\end{array}$ & $\begin{array}{c}\mathbf{9 0} \\
\text { DAT }\end{array}$ & $\begin{array}{c}\mathbf{1 0 5} \\
\text { DAT }\end{array}$ \\
\hline $\mathbf{5}^{\text {th }} \mathbf{J u l y}$ & 0.387 & 0.340 & 0.383 & 0.403 & 0.466 & 0.460 & 0.474 \\
\hline $\mathbf{1 5}^{\text {th July }}$ & 0.389 & 0.350 & 0.390 & 0.456 & 0.488 & 0.495 & 0.499 \\
\hline $\mathbf{2 5}^{\text {th }} \mathbf{J u l y}$ & 0.351 & 0.334 & 0.375 & 0.353 & 0.436 & 0.445 & 0.448 \\
\hline \multicolumn{7}{|c|}{ Varieties } \\
\hline Sarjoo-52 & 0.363 & 0.345 & 0.378 & 0.345 & 0.438 & 0.446 & 0.457 \\
\hline NDR-359 & 0.386 & 0.365 & 0.389 & 0.396 & 0.472 & 0.484 & 0.503 \\
\hline Swarna Sub-1 & 0.376 & 0.356 & 0.385 & 0.385 & 0.454 & 0.463 & 0.475 \\
\hline
\end{tabular}

Table.2 Accumulated of Bright sunshine hours as affected by different growing environment of rice cultivars

\begin{tabular}{|l|l|l|}
\hline \multirow{2}{*}{ Treatments } & \multicolumn{2}{|l|}{ Phenophases/Stage } \\
\hline Growing environment & Bright sun shine (BSS) (hrs.) \\
\cline { 2 - 3 } $\mathbf{5}^{\text {th }}$ July & Vegetative & Reproductive \\
\hline $\mathbf{1 5}^{\text {th }}$ July & 487.4 & 661.6 \\
\hline $\mathbf{2 5}^{\text {th }}$ July & 490.5 & 669.8 \\
\hline & 451.1 & 598.8 \\
\hline Sarjoo-52 & Varieties & \\
\hline NDR-359 & 447.0 & 627.6 \\
\hline Swarna Sub-1 & 461.7 & 633.8 \\
\hline
\end{tabular}


Table.3 Accumulated heliothermal unit as affected by different growing environment of rice cultivars

\begin{tabular}{|l|l|l|}
\hline Treatments & \multicolumn{2}{|l|}{ Phenophases/Stage } \\
\hline Growing environment & \multicolumn{2}{|l|}{ Heliothermal unit ('days hrs.) } \\
\cline { 2 - 3 } & Vegetative & Reproductive \\
\hline $\mathbf{5}^{\text {th }}$ July & 10241.4 & 13414.6 \\
\hline $\mathbf{1 5}^{\text {th }}$ July & 10006.2 & 13244.9 \\
\hline $\mathbf{2 5}^{\text {th }}$ July & 9273.6 & 11179.7 \\
\hline & Varieties & \\
\hline Sarjoo-52 & 10126.3 & 12177.7 \\
\hline NDR-359 & 10092.0 & 12165.4 \\
\hline Swarna Sub-1 & 11604.4 & 12483.2 \\
\hline
\end{tabular}

Table.4 Accumulated photothermal units as affected by different growing environment of rice cultivars

\begin{tabular}{|c|c|c|}
\hline Treatments & \multicolumn{2}{|c|}{ Phenophases/Stage } \\
\hline \multirow[t]{2}{*}{ Growing environment } & \multicolumn{2}{|c|}{ Photothermal unit ("days hrs.) } \\
\hline & Vegetative & Reproductive \\
\hline $5^{\text {th }}$ July & 22270.5 & 28863.9 \\
\hline $15^{\text {th }}$ July & 21435.3 & 28210.6 \\
\hline $25^{\text {th }}$ July & 20160.0 & 24417.8 \\
\hline \multicolumn{3}{|c|}{ Varieties } \\
\hline Sarjoo-52 & 22868.0 & 26241.9 \\
\hline NDR-359 & 21910.2 & 25802.9 \\
\hline Swarna Sub-1 & 23741.0 & 27593.3 \\
\hline
\end{tabular}

Data pertaining to heliothermal unit as affected by different growing environment of rice cultivars have been presented in (Table 3). From table it was revealed that heliothermal unit was recorded highest in $\mathrm{I}^{\text {st }}$ date of transplanting on July $5^{\text {th }}$ ('days hours) followed by July $15^{\text {th }}$ and July $25^{\text {th }}$. Among the varieties highest heliothermal unit at vegetative and reproductive stages were recorded in cultivars Swarna Sub-1 followed by Sarjoo-52 and NDR-359. Data pertaining to photothermal unit as affected by different growing environment of rice cultivars have been presented in (Table 4). From table it was revealed that photothermal unit was recorded highest in $\mathrm{I}^{\text {st }}$ date of transplanting on July $5^{\text {th }}$, at vegetative and reproductive stages as followed by July $15^{\text {th }}$ and July $25^{\text {th }}$. Among the varieties highest photothermal unit at vegetative and reproductive stages was recorded in variety Swarna Sub-1, followed by Sarjoo-52 and NDR-359. Pal et al., (2013) the Higher PTU and HTU were accounted in case of variety PBW-343 followed by WH542 during all the phenophases of wheat for both the years. Wheat crop sown on $20^{\text {th }}$ November (normal) required less photothermal unit as well as heliothermal unit, while, 09th January (late) sowing accounted higher values of PTU and HTU during crop growth period. Timely sown wheat crop (20th November) produced highest yield, while, with every 25 days delay in sowings reduction in yield was accounted 
by 13 to 26.1 percent in the year 2007-08, whereas, 14.6 to 29.3 percent in 2008-09. Diwan et al., (2017) In terms of genotypes heat use efficiency (HUE) was maximum in Mahamaya and radiation use efficiency (RUE) was maximum in MTU-1010.

In conclusion the maximum heat use efficiency ( $\mathrm{g} / \mathrm{m}^{2} / 0^{0}$ days) (0.499) was recorded at II $^{\text {nd }}$ date of transplanting on July $15^{\text {th }}$ at 105 DAT followed by July $5^{\text {th }}(0.474)$ and July $25^{\text {th }}(0.448)$. The highest bright sunshine (hrs.) was recorded at $\mathrm{II}^{\text {st }}$ date of transplanting on (669.8) July $15^{\text {th }}$ followed by (661.6) July $5^{\text {th }}$ and (598.8) July $25^{\text {th }}$ respectively. heliothermal unit was recorded highest in $\mathrm{I}^{\text {st }}$ date of transplanting on July $5^{\text {th }}$ ('days hours) followed by July $15^{\text {th }}$ and July $25^{\text {th }}$. it was revealed that photothermal unit was recorded highest in $\mathrm{I}^{\text {st }}$ date of transplanting on July $5^{\text {th }}$, at vegetative and reproductive stages as followed by July $15^{\text {th }}$ and July $25^{\text {th }}$.

\section{References}

Anonymous, (2013-14).Record Food grain production. Pratiyaogita Darpan. April, 2014: 1618.

Diwan, U.K., Chaudhary, J.L. and Unjan, D. (2017). Variation in Heat and Radiation Use Efficiency of Rice as Influenced by Different Growing Environments and Genotypes, Int. J. Curr. Microbiol. App.
Sci., 6 (11): 48-52.

Dwivedi, J. L. (2011). Status paper on rice in Uttar Pradesh. Rice Knowledge Management Portal (RKMP). http://www.rkmp.co.in.

FAO. World Agriculture (2002).Towards 2015/2030 Summary Report. Food and Agriculture Organization of the United Nations, Rome.

Khus, G.S. (1997). Origin, dispersal, cultivation and variation of Plant Mol. Biol., 35: 25-34.

Nishad, A., Mishra, A.N., Mishra, S.R., Singh, A.K., Chaudhari, R., Kumar, N. and Aryan, R.K. (2018). Effect of heat use efficiency and thermal unit at different phenophases of rice (Oryza sativa L.) Cultivars, J. Pharm. Phyto., 7(5): 1312-1314.

Pal, R.K., Rao, M.N.N. and Murty, N.S. (2013). Agro-meteorological Indices to Predict Plant Stages and Yield of Wheat for Foot Hills of Western Himalayas, International Journal of Agriculture and Food Science Technology, 4(9): 909914.

Samanta, S., Banerjee, S., Mukherjee, A., Patra, P.K. and Chakraborty, P. (2019).

Deriving PAR use efficiency of wet season rice from bright sunshine hour data and canopy characteristics, Mausam, 70(2): 349-358.

\section{How to cite this article:}

Deependra Singh, S. R. Mishra, Rakesh Kushwaha and Ram Singh. 2020. Influence of Bright Sunshine Hours, Photothermal, Heliothermal and HUE of Rice Cultivars Growing under varying Environment. Int.J.Curr.Microbiol.App.Sci. 9(12): 1583-1587. doi: https://doi.org/10.20546/ijcmas.2020.912.187 